\title{
Tracheal Rupture in an Adolescent Female Presenting with Chest Pain and Subcutaneous Emphysema at the Emergency Department: A Case Report
}

\author{
Acil Servise Göğüs Ağrısı ve Deri Altı Amfizemle Başvuran Adölesan Hasta: Tanınız Nedir?
}

\author{
(D) Muhammed Üdürgücü, (D) Nazik Yener, (D) Eda Şahin \\ Ondokuz Mayıs University Faculty of Medicine, Department of Pediatric Critical Care, Samsun, Turkey
}

\section{Abstract}

Tracheal injuries that can lead to life-threatening results are extremely uncommon in children. Although the majority are seen following trauma or invasive procedures, a few paediatric cases exist in the literature of spontaneous tracheal rupture. In the case reported here, a 15-year-old female presented at the Emergency Department with complaints of a sudden onset of chest pain, difficulty breathing, subcutaneous emphysema and pneumomediastinum. On the computed tomography image, a tracheal rupture $8 \mathrm{~mm}$ in size was present in the posterior right lateral section. Using a conservative approach, the patient recovered without any complications. If a patient presents with a sudden onset of breathing difficulty following a severe cough accompanied with subcutaneous emphysema in the presence of chest pain, tracheal rupture should be considered. Our patient presents an extremely rare case of tracheal rupture in childhood. The patient recovered completely without complications using a conservative approach.

Keywords: Tracheal rupture, pneumomediastinum, subcutaneous emphysema

\section{Öz}

Hayatı tehdit eden sonuçlara yol açabilen trakeal yaralanmalar çocuklarda son derece nadir gözlenir. Çoğunlukla invaziv işlemler ve travma sonrası görülmekle birlikte literatürde çocuklarda çok az sayıda olguda spontan trakeal rüptür bildirilmiştir. Çocuk acil servise ani gelişen solunum güçlüğü ve göğüs ağrısı şikayeti ile başvuran 15 yaşında kız hasta deri altı amfizemi ve pnömomediastinum tespit edildi. Çekilen toraks bilgisayarlı tomografide posterior sağ lateral kesiminde $8 \mathrm{~mm}$ boyutunda trakeal rüptür görüldü. Hasta konservatif yaklaşımla komplikasyonsuz iyileşti. Şiddetli öksürük sonrası ani gelişen solunum sıkıntısı, göğüs ağrısı varlığında deri altı amfizem bulguları da eşlik ediyorsa trakeal rüptür mutlaka akla gelmelidir. Çocukluk çağında son derece nadir olması ve konservatif yaklaşımla sorunsuz iyileşmesi nedeniyle bu olguyu sunduk.

Anahtar Kelimeler: Trakeal rüptür, pnomomediastinum, deri altı amfizem

\section{Introduction}

A 15-year-old female presented at the emergency department with complaints of a sudden onset of chest pain and difficulty breathing. Subcutaneous emphysema was detected on the patient's neck, with no history of foreign body aspiration, trauma or invasive procedures. On the computed tomography (CT) image, a tracheal rupture $8 \mathrm{~mm}$ in size was present in the posterior right lateral section. Using a conservative approach, the patient recovered without any complications. Tracheal injuries that can lead to life-threatening results are extremely uncommon in children. If a patient presents with a sudden onset of breathing difficulty following severe cough, accompanied with subcutaneous emphysema and chest pain, tracheal rupture should be considered.

Address for Correspondence/Yazışma Adresi: Muhammed Üdürgücü, Ondokuz Mayıs University Faculty of Medicine, Department of Pediatric Critical Care, Samsun, Turkey

E-mail: udurguxu@gmail.com ORCID ID: orcid.org/0000-0003-2931-556X Received/Geliş Tarihi: 04.05.2019 Accepted/Kabul Tarihi: 14.12.2020 


\section{Case Report}

A previously healthy 15-year-old female presented at the paediatric emergency department with complaints of cough, respiratory problems, severe chest pain and fever. It was learnt that the cough and fever had been ongoing for three days, and on the day of admission, there had been a sudden onset of chest pain and breathing difficulty. On questioning the patient, it was learnt that there was no foreign body or food aspiration. Her medical and family histories were unremarkable. Her height was $159 \mathrm{~cm}$ and weight was $50 \mathrm{~kg}$. At the time of presentation, the patient was fully conscious, and her respiratory rate was $36 / \mathrm{min}$, temperature was 37.8 ${ }^{\circ} \mathrm{C}$, pulse was 96/min and blood pressure was 112/63 mm/ Hg. Her oxygen saturation on room air was 90\%. The first to $99^{\text {th }}$ percentiles of the patient's heart rate and respiratory rate were within normal ranges. On physical examination, there was a swelling in the anterior neck region extending bilaterally. The oropharynx was hyperaemic, without exudates and the external auditory canal and eardrum were normal on examination. The patient was taking short breaths with difficulty. However, on auscultation of lungs bilaterally, no pathological sound, stridor or wheezing was heard. Head and neck postures were normal. On palpation of the neck, there was a subcutaneous crepitation at the level of the clavicle, extending as far as the back of the neck bilaterally. There were no signs of trauma. On examining other systems, the findings were normal. Viral infection of the upper respiratory tract was considered at the first examination.

On the posteroanterior pulmonary radiograph, the lung parenchyma was normal, selective pneumomediastinum was seen along the heart borders and free air was seen between the subcutaneous muscle tissues and fascia in the chest wall and neck region (Figure 1). The venous blood gas values were $\mathrm{pH}: 7.42, \mathrm{pCO}_{2}: 42 \mathrm{mmHg}, \mathrm{pO}_{2}: 44 \mathrm{mmHg}, \mathrm{HCO}_{3}: 25 \mathrm{mEq} / \mathrm{L}$ and lactate: $1.67 \mathrm{mmol} / \mathrm{L}$. Blood count, serum electrolytes and liver and kidney function tests were within normal limits. The patient was admitted to the paediatric intensive care unit, and the treatment was started with inhaled oxygen using a reservoir mask. Oxygen saturation increased to 96\%. On the thoracic CT image, widespread emphysema was observed in the subcutaneous soft tissues, between the muscle planes, the mediastinum and peribronchial areas and the posterior right lateral section of the trachea. A rupture defect was determined, $8 \mathrm{~mm}$ in size and $1 \mathrm{~cm}$ above the abdomen at the level of the fourth thoracic vertebra (Figure 2). Intravenous ceftriaxone was started. On the second day of hospitalisation, subcutaneous crepitation was detected; however, the respiratory pattern was not impaired. Oxygen therapy with a reservoir mask was continued. Moreover, over the subsequent days, the patient recovered without the need for any invasive procedure. On the tenth day of follow-up, the patient recovered fully and was discharged.

\section{Discussion}

In childhood, chest pain is mostly caused by musculoskeletal, idiopathic and psychogenic causes and less frequently by disorders of the respiratory, cardiac and gastrointestinal systems. ${ }^{1}$ In our patient, the sudden onset of pain and accompanying subcutaneous crepitation primarily suggested air leak syndromes.

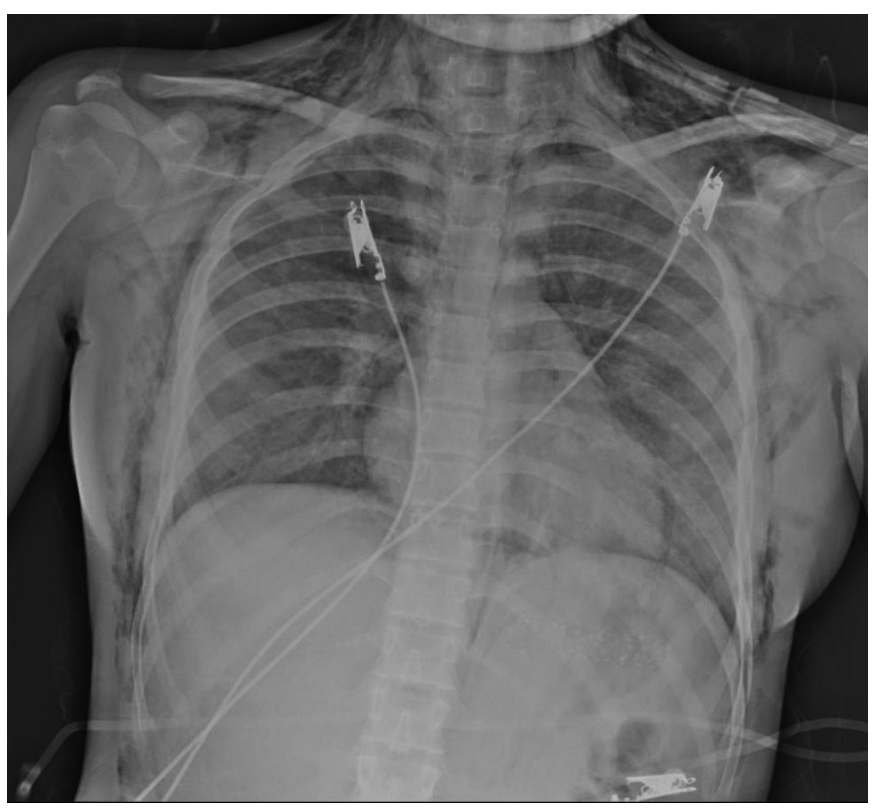

Figure 1. Posteroanterior chest radiograph of the patient showing air leakage around the heart and in subcutaneous chest tissues

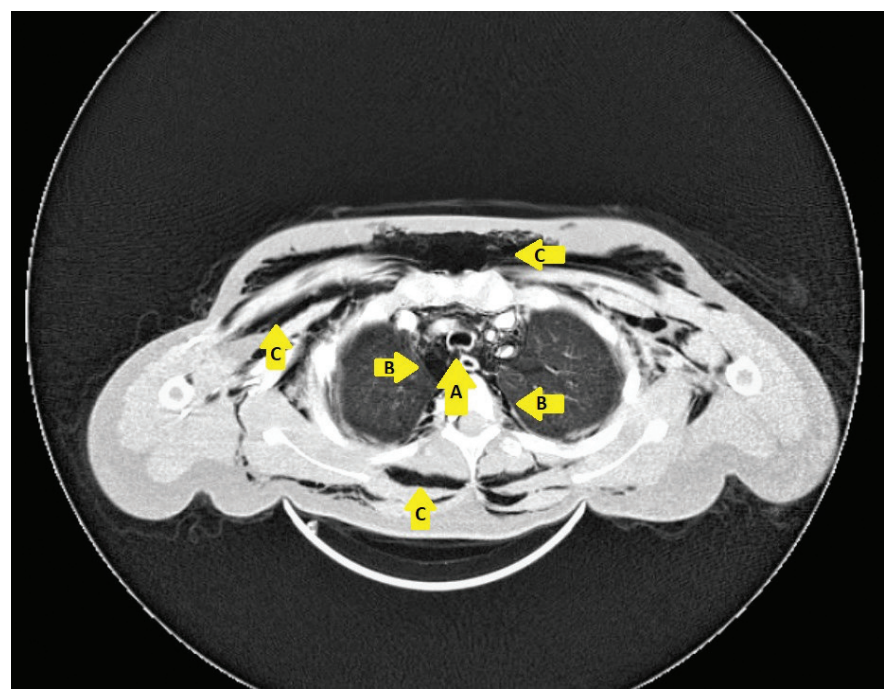

Figure 2. Computed tomography slices of the thorax: (A) rupture defect in the posterior right section of the trachea, (B) selective air leakage in the mediastinal region and $(C)$ subcutaneous emphysema progressing to the subcutaneous tissues and fascia 
Tracheal rupture is rarely seen in childhood, but it is an injury that can cause life-threatening complications. Very few cases of spontaneous tracheal rupture in childhood have been reported in the literature. The vast majority of spontaneous tracheal ruptures occur in adult patients and are associated with obstructive pulmonary disease, bronchial asthma, chronic pulmonary diseases, such as bronchitis, and a history of radiotherapy or chronic use of steroids. ${ }^{2}$ In our patient, there was no history of an interventional procedure, which could have caused the tracheal rupture, no sign of trauma to the neck or chest, no history of drug use and no known chronic pulmonary disease. In cases of unexplained spontaneous tracheal rupture, conditions that lead to an increase in the intratracheal pressure, while the glottis is closed, such as coughing and vomiting, are thought to be responsible. ${ }^{3}$ Our patient had a history of upper respiratory tract infection, accompanied with a cough, and it was thought that the tracheal rupture had developed due to increased intratracheal pressure following a severe coughing attack.

Clinical findings guide the diagnosis of tracheal rupture. Small ruptures may cause chest pain and haemoptysis, while large ruptures can lead to short breaths taken with difficulty and cyanosis. If there is a concomitant pleural laceration, there may be accompanying pneumothorax. ${ }^{4}$ Air leakage associated with the rupture causes crepitation by spreading to subcutaneous tissues in the neck and upper thorax, leading to subcutaneous emphysema. Moreover, although subcutaneous emphysema can facilitate diagnosis, it is not specific to tracheal rupture. ${ }^{4}$

While accompanying pneumomediastinum and subcutaneous emphysema have been determined more often in the literature, pneumothorax has been found to be less common. ${ }^{4}$ In our patient, pneumomediastinum and subcutaneous emphysema were both present, but no pneumothorax was detected on the pulmonary radiograph. Although bronchoscopy is superior in diagnosing tracheal rupture, thoracic $\mathrm{CT}$ is extremely valuable in both the visualisation of the rupture and evaluation of complications. It is reported that the success rate of $C T$ in the determination of tracheal rupture is $85 \% .^{5}$ When imaging is insufficient, bronchoscopy can be used. ${ }^{6}$ In our patient, since tracheal rupture was detected on $\mathrm{CT}$ image in the right posterior region, the patient did not undergo bronchoscopy under sedoanalgesia to avoid the risk of further damaging the trachea. The posterior left membranous region of the trachea is anatomically supported by the oesophagus, so lesions usually occur on the right side. ${ }^{7}$

In tracheal rupture, the treatment options are using a conservative approach and surgical repair in selected patients. Surgery is recommended in patients with trachea obstructed by mediastinal structures and horizontal lacerations larger than one-third of the trachea diameter, accompanying organ injuries such as oesophagus injury and progressive pneumomediastinum. Conservative follow-up is recommended for lacerations smaller than $2 \mathrm{~cm}{ }^{4,8}$ In patients with a requirement for mechanical ventilation, placing the endotracheal tube distal of the lesion and using a cuffed tube are recommended. ${ }^{9}$ Tracheal ruptures have been reported to heal in two to four weeks. ${ }^{7}$ Our patient did not require intubation and fully recovered using a conservative approach. Although there is no clear consensus on the subject of starting empirical antibiotics to treat mediastinitis in patients with tracheal rupture, our patient was started on antibiotics on admission, which were continued for 10 days.

In conclusion, a simple cough, which is a commonly seen symptom in paediatrics, can very rarely lead to significant injury of organs, such as the trachea, leading to life-threatening tracheal rupture, without any underlying cause. When a child presents with a sudden onset of respiratory problems following severe cough and findings of subcutaneous emphysema are present accompanied with chest pain, tracheal rupture should be considered in the differential diagnosis.

\section{Ethics}

Informed Consent: Informed consent was obtained.

Peer-review: Externally and internally peer-reviewed.

\section{Authorship Contributions}

Concept: N.Y., M.Ü., Design: M.Ü., Data Collection or Processing: M.Ü., Analysis or Interpreation: M.Ü., Literature Search:. N.Y., Resources and Funding: E.Ş., Writing: M.Ü.

Conflict of Interest: No conflict of interest was declared by the authors.

Financial Disclosure: The authors declared that this study received no financial support.

\section{References}

1. Aygun E, Aygun ST, Uysal T, Aygun F, Dursun H, ve ark. Aetiological evaluation of chest pain in childhood and adolescence. Cardiol Young. 2020;30:617-23.

2. Rousié $C$, Van Damme H, Radermecker MA, Reginster $P$, Tecqmenne C, et al. Spontaneous tracheal rupture: a case report. Acta Chir Belg. 2004;104:204-8.

3. van der Klooster JM, Grootendorst AF, Ophof PJ, Brouwers JW. Pneumomediastinum: an unusual complication of bronchial asthma in a young man. Neth J Med. 1998;52:150-4.

4. Deja M, Menk $M$, Heidenhain C, Spies $C D$, Heymann $A$, et al. Strategies for diagnosis and treatment of iatrogenic tracheal ruptures. Minerva Anestesiol. 2011;77:1155-66.

5. Chen JD, Shanmuganathan K, Mirvis SE, Killeen KL, Dutton RP. Using $C T$ to diagnose tracheal rupture. AJR Am J Roentgenol. 2001;176:1273-80. 
6. Hashem B, Smith JK, Davis WB. A 63-year-old woman with subcutaneous emphysema following endotracheal intubation. Chest. 2005;128:434-8.

7. Conti $M$, Pougeoise $M$, Wurtz $A$, Porte $H$, Fourrier $F$, et al. Management of postintubation tracheobronchial ruptures. Chest. 2006;130:412-8.
8. Jougon J, Ballester M, Choukroun E, Dubrez J, Reboul G, et al. Conservative treatment for postintubation tracheobronchial rupture. Ann Thorac Surg. 2000;69:216-20.

9. Kaloud H, Smolle-Juettner FM, Prause G, List WF. Iatrogenic ruptures of the tracheobronchial tree. Chest. 1997;112:774-8. 